\title{
Correction to: A Multicenter Study to Evaluate Harmonization of Assays for C-Terminal Telopeptides of Type I Collagen (B-CTX): A Report from the IFCC-IOF Committee for Bone Metabolism (C-BM)
}

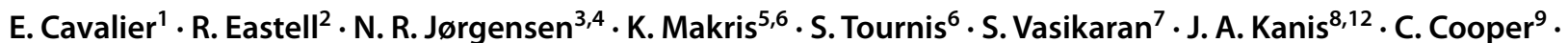 \\ H. Pottel ${ }^{10} \cdot$ H. A. Morris ${ }^{11}$. on behalf of the IFCC-IOF Committee for Bone Metabolism (C-BM)
}

Accepted: 15 March 2021 / Published online: 17 April 2021

(c) The Author(s) 2021

\section{Correction to: Calcified Tissue International https://doi.org/10.1007/s00223-021-00816-5}

The original version of this article unfortunately contained a mistake in Fig. 1. The corrected Fig. 1 is given below.

The original article can be found online at https://doi.org/10.1007/ s00223-021-00816-5.

E. Cavalier

Etienne.cavalier@chu.ulg.ac.be

1 Department of Clinical Chemistry, University of Liège, CHU Sart-Tilman, Domaine du Sart-Tilman, B-4000 Liège, Belgium

2 Mellanby Centre for Bone Research, University of Sheffield, Sheffield, UK

3 Department of Clinical Biochemistry, Rigshospitalet, 2600 Glostrup, Denmark

4 Department of Clinical Medicine, Faculty of Health and Medical Sciences, University of Copenhagen, Copenhagen, Denmark

5 Clinical Biochemistry Department, KAT General Hospital, 14561 Athens, Greece
6 Laboratory for Research of the Musculoskeletal System "Th. Garofalidis", Medical School, University of Athens, 14561 Athens, Greece

7 PathWest Laboratory Medicine, Fiona Stanley Hospital, Murdoch, WA 6150, Australia

8 Centre for Metabolic Bone Diseases, University of Sheffield Medical School, Beech Hill Road, Sheffield S10 2RX, UK

9 The MRC Epidemiology Resource Centre, Southampton General Hospital, University of Southampton, Southampton SO16 6YD, UK

10 Department of Public Health and Primary Care, KU Leuven Campus Kulak Kortrijk, Kortrijk, Belgium

11 School of Pharmacy and Medical Sciences, University of South Australia, Adelaide, SA 5000, Australia

12 Mary McKillop Institute for Health Research, Australian Catholic University, Melbourne, Australia 


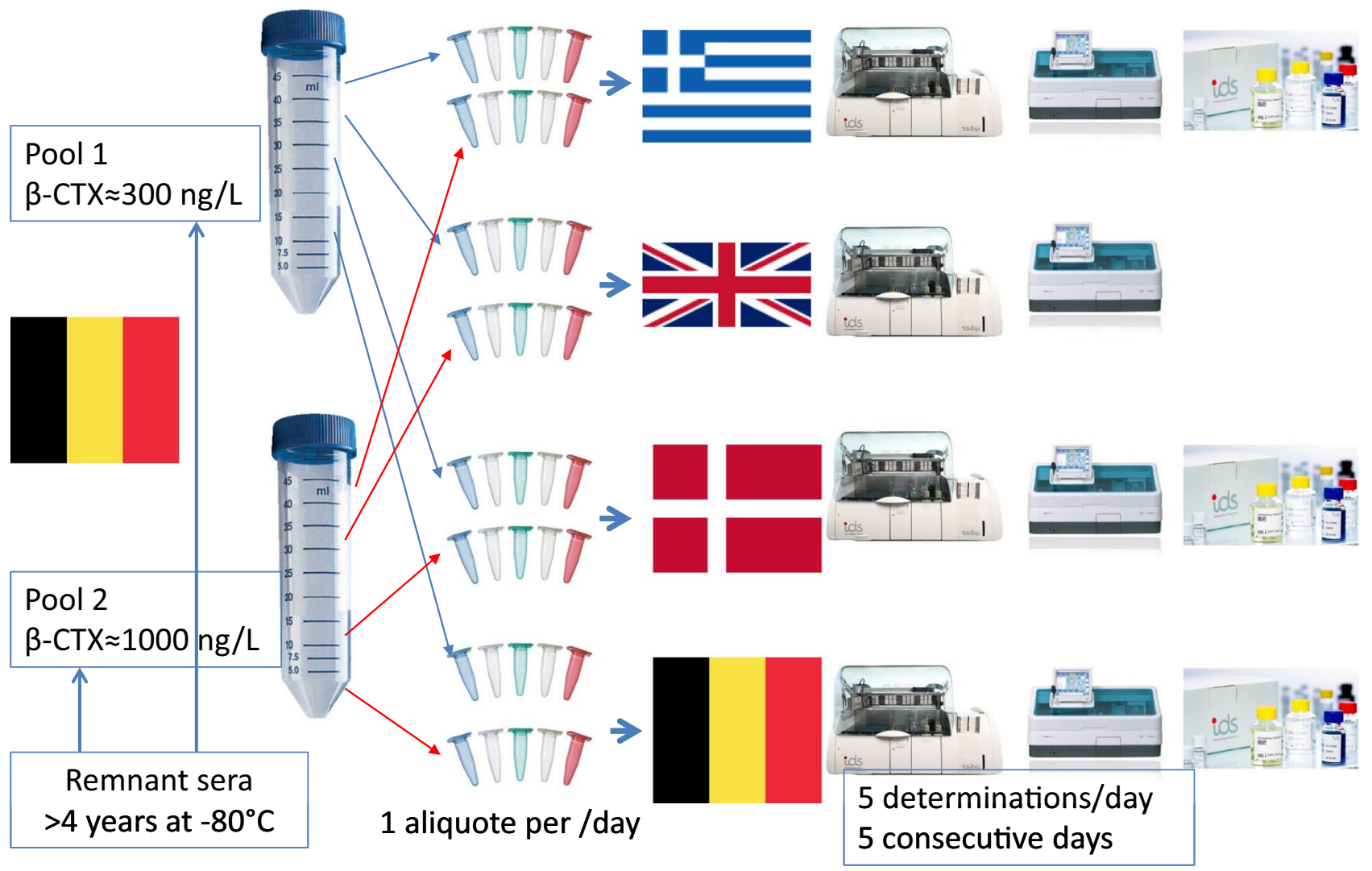

Fig. 1 Preparation of the pools for the performance study evaluation

Open Access This article is licensed under a Creative Commons Attribution 4.0 International License, which permits use, sharing, adaptation, distribution and reproduction in any medium or format, as long as you give appropriate credit to the original author(s) and the source, provide a link to the Creative Commons licence, and indicate if changes were made. The images or other third party material in this article are included in the article's Creative Commons licence, unless indicated otherwise in a credit line to the material. If material is not included in the article's Creative Commons licence and your intended use is not permitted by statutory regulation or exceeds the permitted use, you will need to obtain permission directly from the copyright holder. To view a copy of this licence, visit http://creativecommons.org/licenses/by/4.0/.

Publisher's Note Springer Nature remains neutral with regard to jurisdictional claims in published maps and institutional affiliations. 